\title{
Effect of environmental variability on habitat selection, diet, provisioning behaviour and chick growth in yellow-nosed albatrosses
}

\author{
David Pinaud*, Yves Cherel, Henri Weimerskirch \\ Centre d'Etudes Biologiques de Chizé, CNRS-UPR1934, 79360 Villiers-en-Bois, France
}

\begin{abstract}
To understand how seabird breeding performance is influenced by environmental variability, it is necessary to compare acquisition processes between contrasted situations, and their consequence for reproduction. We present results on variations in distribution at sea, habitat selection, diet and provisioning behaviour of the yellow-nosed albatross Thalassarche chlororhynchos from Amsterdam Island, and their consequence for chick growth, during 2 years, 1996 and 2001, with contrasted environmental conditions. The position of thermal fronts changed between the 2 years, and the waters around Amsterdam were colder in 2001 than in 1996. Satellite tracking and compositional analysis show that in 2001 birds foraged farther and in colder oceanic waters than in 1996, resulting in poorer foraging success in 2001. During both years, fish dominated the diet, with minor interannual differences: albatrosses fed more on fish (including a higher proportion of the nomeid Cubiceps caeruleus) and less on squid and crustaceans in 1996. Nestling provisioning was half the rate in 2001 compared to 1996, and this difference was mainly due to longer trips in 2001, with a bimodal trip length distribution. Consequently, chick growth differed significantly, with lighter chicks at fledging being produced in 2001 compared to 1996, although wing length was similar between the 2 years. This study indicates that, during unfavourable conditions, yellow-nosed albatrosses are able to increase foraging effort by searching for prey at greater distances from the nest, at the expense of offspring condition.
\end{abstract}

KEY WORDS: Environmental variability · Sub-tropical albatross · Yellow-nosed albatross . Thalassarche chlororhynchos · Habitat selection · Satellite telemetry · Cubiceps caeruleus

\section{INTRODUCTION}

Oceans are considered to be highly variable ecosystems, with substantial unpredictable and cyclical fluctuations in oceanographic parameters, such as the El Niño-Southern Oscillation (Schreiber \& Schreiber 1984). This variability often affects all levels of the trophic web and especially top-predators (Croxall 1992). Such effects on seabirds have increasingly been documented (e.g. Weimerskirch et al. 2001, Inchausti et al. 2003), with the productivity and recruitment of some seabird populations being negatively correlated to sea surface temperatures (SST), a parameter often used to describe oceanographic conditions affecting marine ecosystem structure (Hyrenbach \& Veit 2003). Conversely, some seabird species can be positively affected by warmer SST (Pinaud \& Weimerskirch 2002, Inchausti et al. 2003). Although relationships between oceanographic parameters and breeding performance have increasingly been documented, the reasons why such relationships exist are not well understood. The connection between the marine environment and breeding performance is likely mediated through resource acquisition and allocation processes (Stearns 1992), with variations in the physical marine environment affecting the availability and accessibility of resources for foraging seabirds, and therefore their allocation of resources toward maintenance and reproduction.

Oceanic seabirds such as procellariiforms are typically central-place foragers during reproduction, cov- 
ering long distances between resource and breeding grounds. They forage for presumably patchy and unpredictable marine resources (Ashmole 1971). However, prey distribution can be temporally and spatially predictable, when associated with environmental features, such as frontal zones, shelves and shelf slopes (Hunt 1991). The temporal and spatial separation between feeding areas and breeding grounds represents an important energetic constraint during reproduction (Orians \& Pearson 1979). Thus, resource availability within the foraging range of a central-foraging species should be crucial for its successful reproduction.

Several studies have shown that interannual differences in distribution and distance to the colony (Veit \& Prince 1997), diet (e.g. Croxall et al. 1999, Suryan et al. 2002) and provisioning rate (e.g. Weimerskirch et al. 2001) have significant consequences for reproductive parameters, such as chick mortality, growth and body condition (e.g. Xavier et al. 2003). To explain the differences observed in breeding parameters between years, authors have mentioned differences in acquisition processes. However, few have directly examined the differences in foraging behaviour at sea that may be associated with environmental variation, and their consequences for allocation (see Barlow \& Croxall 2002). In particular, most studies have been carried out in polar and temperate waters, with few in sub-tropical or tropical marine ecosystems, where productivity is lower.

In the present study, we describe, during 2 years with contrasted environmental conditions, the distribution at sea, habitat selection, diet, provisioning behaviour and chick growth of yellow-nosed albatrosses Thalassarche chlororhynchos to examine the degree of flexibility of the foraging behaviour of a pelagic seabird in sub-tropical waters, and its consequences for reproductive success.

\section{MATERIALS AND METHODS}

Field procedures. The study was carried out at Pointe d'Entrecasteaux (3751' $\left.42^{\prime \prime} \mathrm{S}, 7^{\circ} 31^{\prime} 08^{\prime \prime} \mathrm{E}\right)$ on Amsterdam Island, in January 1996 and January 2001, during the chick-rearing period. Chicks hatch in early December, are left alone on the nest in late December, and fledge in early April (Jouventin et al. 1983). This species is considered as sexually monomorphic (in Marchant \& Higgins 1990). The study was carried out in a colony where the provisioning behaviour has been observed since 1990 (Weimerskirch et al. 2001). In this study colony of ca. 150 pairs, adult birds were identified with a metal band, a plastic band, and 1 member of the pair was marked with a spot of picric acid on the breast to allow identification at a distance.
From 5 to 18 January 1996 and from 15 January to 3 February 2001, 2 people continuously observed 40 and 60 nests, respectively, from dawn (ca. 05:00 h) to dusk (ca. 19:00 h), to monitor the visits of the individual parents to the chick. Adults do not visit the colonies at night (Weimerskirch et al. 2001). The times of arrival and departure of the adults were noted continuously, yielding the duration of individual foraging trips. We weighed all chicks with a $5 \mathrm{~kg}$ spring balance accurate to $1 \%$ at $06: 00 \mathrm{~h}$ and $18: 00 \mathrm{~h}$ (local time), in order to assess feeding rate and meal size. Whenever feeding was observed, we weighed the chick within an hour of the departure of the parent. No negative impact of the frequent weighing of chicks was noted; they do not regurgitate food when they are accustomed to handling since hatching. Laying and hatching are very synchronous within a colony. No difference was observed in hatching dates between the 2 years $\left(\chi^{2}{ }_{1}=\right.$ $9 \times 10^{-6}, \mathrm{p}=0.98$ ). To measure chick growth, a random sub-sample of the same chicks (50 in 1996 and 14 in 2001) was weighed in the provisioning colony at different ages (around 44, 54, 67 and 103 d old), from midJanuary to late March, just before fledging, without interaction with any treatment (satellite tracking or diet sample). We measured wing length in late March, prior to fledging. During the 2 years, in mid-January and in mid-February, we weighed random samples of adults just after they had delivered a meal, with a $5 \mathrm{~kg}$ spring balance accurate to $1 \%$.

Between 1 and 15 January 1996 and between 15 and 30 January 2001, 11 and 12 adults, respectively, were fitted with $32 \mathrm{~g}$ satellite transmitters (platform terminal transmitters, PTT100, Microwave Telemetry). The PTTs were fitted onto the back feathers with adhesive tape and left on the birds for several consecutive foraging trips. The overall weight of the instrumentation carried by each bird represented $1.6 \%$ of the average body mass of adult yellow-nosed albatross, i.e. within the recommended specifications (Phillips et al. 2003).

Food samples were either collected from adults before they fed their chicks or from chicks just after a feeding event during the provisioning study. In this species, regurgitation is generally spontaneous when the bird is handled for the first time. Only 1 sample was collected for each adult or chick. Food samples were frozen and returned to the Centre d'Etudes Biologiques de Chizé for analysis.

Data analysis. Environmental data: Environmental data, such as bathymetry (at $0.08^{\circ}$ resolution), SST and SST anomalies (SSTa, weekly data at $1^{\circ}$ resolution), were used to describe oceanographic conditions and were extracted from the IGOSS web site (http://ingrid. ldeo.columbia.edu/SOURCES/.IGOSS) for a zone from 50.5 to $99.5^{\circ} \mathrm{E}$ and from 32.5 to $48.5^{\circ} \mathrm{S}$, corresponding 
to the known distribution at sea of this population (Weimerskirch et al. 1986). SSTa corresponded to the difference between the actual value and adjusted 1950 to 1979 climatology (Reynolds \& Smith 1994). Data were projected over a grid of 94 rows $\times 238$ columns using ArcView 3.2 GIS (ESRI), corresponding to a cell size of $20 \mathrm{~km}$ (observed average maximum Argos quality class). Weekly SST and SSTa (Reynolds \& Smith 1994) were extracted for the weeks 5 to 12 January 1996 and 17 to 24 January 2001, according to each bird trip. Data were projected in GIS over the grid using Albers' 'equal area conic projection' in order to respect distances and areas. Bathymetry classes correspond to: oceanic (>3000 m, Oc), peri-insular slope (1000 to $3000 \mathrm{~m}$, P. Slope) and coastal waters $(\leq 1000 \mathrm{~m}, C W)$. SST classes were defined according to Holliday \& Read (1998): Agulhas return current front $\left(16\right.$ to $\left.18^{\circ} \mathrm{C}, A R F\right)$, sub-tropical waters $\left(14\right.$ to $\left.16^{\circ} \mathrm{C}, s T W\right)$, sub-tropical front $\left(12\right.$ to $\left.14^{\circ} \mathrm{C}, S T F\right)$, sub-Antarctic surface waters (11 to $\left.12^{\circ} \mathrm{C}, S A S W\right)$, sub-Antarctic front $\left(9\right.$ to $11^{\circ} \mathrm{C}$, $S A F)$, polar frontal zone $\left(6\right.$ to $\left.9^{\circ} \mathrm{C}, P F Z\right)$ and polar front $\left(<6^{\circ} \mathrm{CPF}\right)$.

Albatross data: Because chicks lose mass on the nest from defecation and respiration, the difference in mass between the morning weighing and the mass after feeding is not exactly the mass of the meal (Ricklefs et al. 1985). Average mass loss per day was calculated for 23 chicks (weighed during at least $4 \mathrm{~d}$ without feeding). We used the equation $W_{t}=W_{0} \mathrm{e}^{-k t}$ (Croxall 1982), where $W_{t}$ is the body mass at time $t$, $W_{0}$ is the body mass at feeding, and $k$ is the proportion of mass lost per day. We obtained $k=0.11 \pm 0.02$ $\left(\mathrm{r}^{2}=0.84, \mathrm{p}=0.001\right)$ for 28 chicks with a known feeding date and multiple-mass data. We estimated by this method the mass of the chick before feeding, according to the time elapsed between weighing and feeding. The provisioning rate was calculated as the total meal mass delivered per day at a given nest by the 2 adults for a period of 5 d, from 14 to 18 January 1996 or from 16 to 20 January 2001. As study periods did not strictly overlap and trip duration could increase with chick age at the overall breeding season scale, we compared the trip length between 2 periods in 1996, corresponding to the study dates in 1996 and 2001 (on the one hand, first half of January, and, on the other hand, the second half of January). We used data from Weimerskirch et al. (2001) for adults fitted with a VHF transmitter and an automated system, which allowed continuous recording of nest attendance (see Weimerskirch et al. 2001 for details). No difference was detected in trip duration between the first half of January (5 to 15) and the second half (15 January to 3 February, Wilcoxon rank test with 1 random trip by individual for each period, $\mathrm{n}=27$, $Z=-1.63, \mathrm{p}=0.08)$.
Distribution at sea and habitat use: The time spent at sea over the grid was calculated for each bird, to compare the foraging distribution between the 2 years. Since a third Argos system satellite was effective in January 2001, the time between subsequent localisations was lower in 2001 (2.5 h) than in 1996 (4.8 h); more localisations were obtained in 2001 than in 1996, but in the same proportion according to the Argos quality class. This difference may bias the comparison of movement rates between the 2 years (Hays et al. 2001) and, consequently, the calculation of the time spent in each grid cell. In order to take this into account, a percentage (38 to $62 \%$, according to each Argos class) of 2001 locations was randomly removed, to eliminate significant differences in the time between fixes in both years (in mean $4.8 \mathrm{~h}$ ). Argos locations were filtered, first, by excluding low-quality fixes (Class B) and, second, by calculating the speed between consecutive fixes and removing, with an iterative process, all locations that required unrealistic flying speeds, exceeding $75 \mathrm{~km} \mathrm{~h}^{-1}$ (maximum speed calculated from Pennycuick [1982] and recorded from Alerstam et al. [1993]).

We used GIS to overlay habitat data and bird positions and to extract the time spent in each cell of the matrix. One trip per bird was randomly chosen, so 11 trips in 1996 and 12 trips in 2001 were used for the analysis. To assess habitat selection, we used compositional analysis (Aebischer et al. 1993), which determines the relative use of each habitat and allows statistical comparison between factors such as year using MANOVA. For each bird, the proportions of the total individual foraging time in a given habitat (defining 'used proportions') were compared to the proportions of the number of cells for this habitat (defining 'available proportions') over the study area to facilitate the habitat use comparison between years. To perform the analysis, as zeros pose some calculation problems, we pooled habitats that were not utilised (Aebischer et al. 1993), and STF, SASW, SAF, PFZ and PF were pooled in the category 'others'. In the case of unused habitats, as recommended by Aebischer et al. (1993), the zeros were replaced by the smallest proportion observed in any habitat divided by 10 .

Diet: Food analysis followed Cherel et al. (2000). Each sample was thawed and drained, and the accumulated cephalopod beaks (without flesh attached) were subsequently sorted. Fresh remains were divided into broad prey classes (fish, cephalopods, crustaceans and others), which were weighed to calculate their proportion by fresh mass in the diet. Identification of prey relied almost totally on the examination of otoliths and bones for fish, chitinised beaks for cephalopods and exoskeletons for crustaceans. Items were identified by comparison with material held in our own col- 
lection and by reference to the available literature, including Smale et al. (1995) for fish, Clarke (1986) for cephalopods and Murano (1999) for crustaceans.

Statistics: For statistics we used Systat 9 and R software (R Development Core Team 2003). Normality and homoscedasticity were verified for each statistical test. When data diverged from a normal distribution, nonparametric tests were used. Due to a lack of statistical robustness arising from repeated samples taken from the same individual (pseudo-replication), 1 sample (concerning meal, trip, or mass) was randomly taken per individual. To also avoid a lack of independence in samples in connection with treatments and measures (i.e. the equipment of an adult with a PTT could bias the estimation of the provisioning rate for its chick), samples were taken without interaction with a treatment (PTT or diet sample). This approach explains the difference in sample size observed in the different tests. Results given are means $( \pm \mathrm{SD})$, with a significance level at 0.05 .

\section{RESULTS}

\section{Interannual differences in environmental conditions and habitat use}

Environmental conditions differed strongly between years. Comparison of SST anomalies between the 2 years indicate that waters around the colony were warmer in 1996 than in 2001 (Fig. 1), according to the base period from 1950 to 1979. The position of isotherms and fronts changed around Amsterdam Island, notably with the $18^{\circ} \mathrm{C}$ isotherm (corresponding to the ARS northern boundary, Holliday \& Read 1998) being located further south in 1996 than in 2001. A shift in frontal positions was also observed west of the study area, at 50 to $60^{\circ} \mathrm{E}$, but with a shift of 1 to $2^{\circ}$ latitude further south in 2001 than in 1996.

Birds foraged in different zones between years (Fig. 1) and farther from Amsterdam in 2001 than in 1996 (Fig. 2), leading to different habitats being used

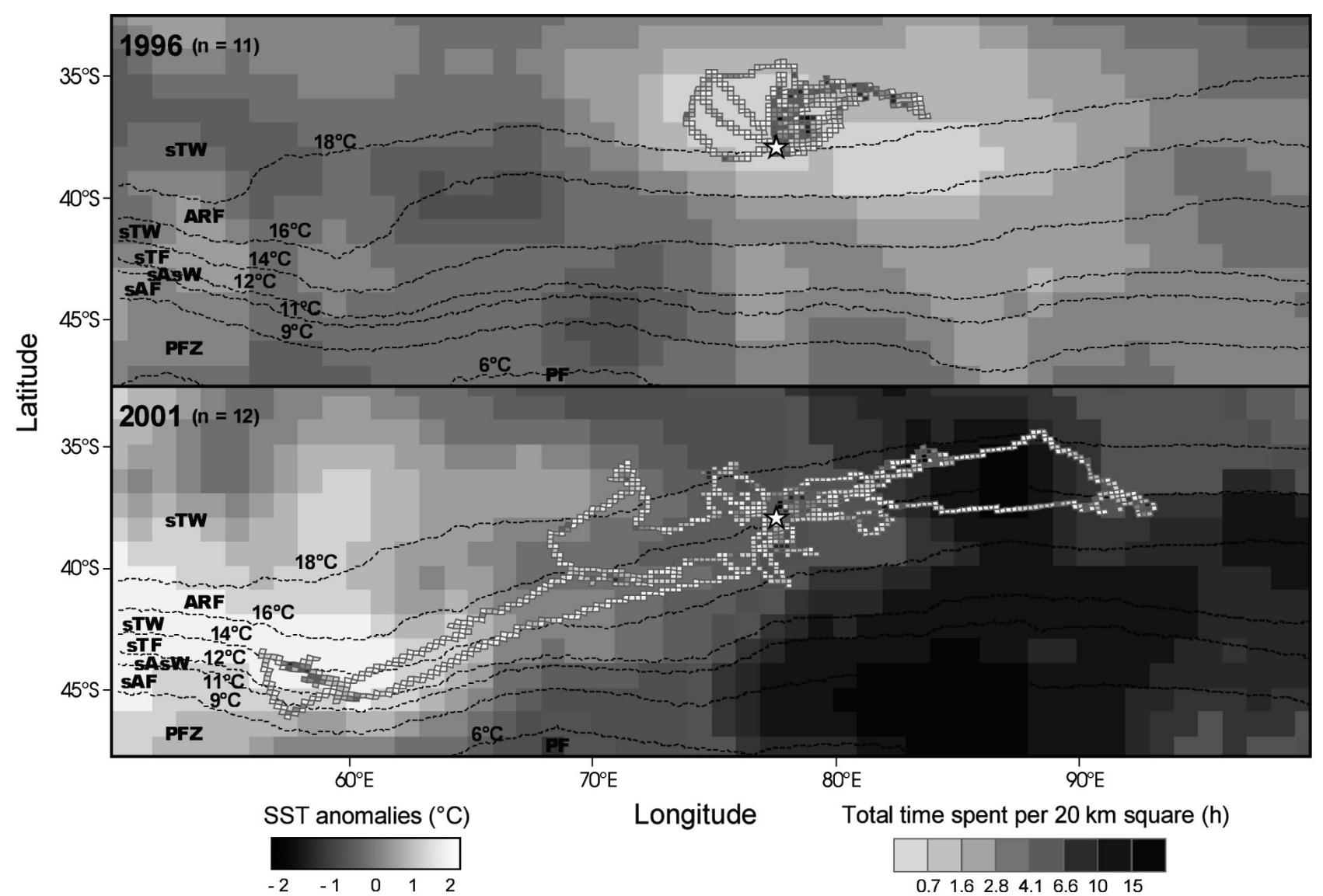

Fig. 1. Thalassarche chlororhynchos. Map showing, for January 1996 and 2001, distribution at sea using satellite tracking, with the time spent per $20 \mathrm{~km}$ cell (quantiles in $1 \mathrm{~h}$, grey squares), sea surface temperature (SST) isotherms defining oceanographic domains $\left({ }^{\circ} \mathrm{C}\right.$, dotted lines) and SST anomalies (SSTa) determined from 1950 to 1979 adjusted climatology $\left({ }^{\circ} \mathrm{C}\right.$, grey background) (oceanographic domains: $A R F$, Aguhlas current return front; $s T W$, sub-tropical waters; $s T F$, sub-tropical front; $s A s W$, sub-Antarctic south waters; $S A F$, sub-Antarctic front; $P F Z$, polar frontal zone; $P F$, polar front; white star, Amsterdam colony) 


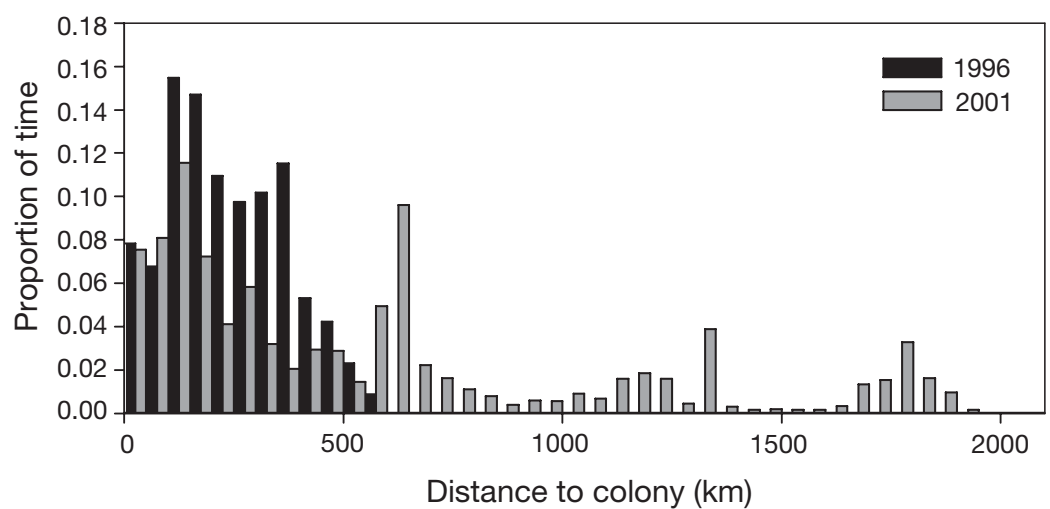

Fig. 2. Thalassarche chlororhynchos. Time spent at sea (per $20 \mathrm{~km}$ cell) in relation to distance to the colony, for satellite-tracked yellow-nosed albatross from Amsterdam Island, for January $1996(\mathrm{n}=11)$ and $2001(\mathrm{n}=12)$

\section{Diet}

In January 1996 and 2001, 41 and 25 food samples were collected, allowing the identification of 229 and 162 prey items, respectively, to species. The proportions by mass of each prey group differed significantly between years $\left(\chi^{2}{ }_{3}=69.05, \mathrm{p}<0.001\right)$. Fish predominated and were observed in 100 and $92 \%$ of the samples in 1996 and 2001, representing 92.0 and $80.7 \%$ of the diet by fresh mass, respectively. Three fish species dominated during both years: the nomeid Cubiceps caeruleus, the scomberesocid Scomberesox saurus and the phosichthyid Phosichthys argenteus (Table 2). C. caeruleus showed

(Table 1). Habitat use according to bathymetric features was not random and differed from available proportions (Wilk's $\lambda=0.092, F_{2,20}=98.32, \mathrm{p}<0.001$ ). The peri-insular slopes were preferred to oceanic and coastal waters (Fig. 3A), indicating that birds primarily used waters in the vicinity of Amsterdam Island. No significant difference was detected between years (Wilk's $\lambda=0.841, F_{2,20}=1.88, \mathrm{p}=0.178$ ), probably because of the high contribution of locations around the colony from commuting birds. According to oceanographic domains as defined by SST, the habitats used were different from the available habitats (Wilk's $\lambda=0.428, F_{2,20}=13.37, \mathrm{p}<0.001$ ), indicating that birds selected particular habitats, with a preference for the Agulhas return current and sub-tropical waters. Probably due to changes in the environment, an interannual difference in habitat use was detected (Wilk's $\lambda=0.147, F_{2,20}=52.25, \mathrm{p}<0.001$ ), with the selection of warmer waters in 1996 (Fig. 3B). In 1996, sub-tropical waters were selected $\left(\chi^{2}{ }_{2}=78.71, \mathrm{p}<\right.$ 0.001), whereas in 2001 colder waters like the Agulhas return current were selected $\left(\chi^{2}{ }_{2}=21.95, \mathrm{p}<0.001\right)$.

Table 1. Thalassarche chlororhynchos. Summarised results for habitat selection using compositional analysis, according to each habitat variable. Significant $\mathrm{p}$-values are in bold. Triple signs in habitat ranking indicate significant differ-

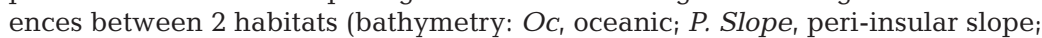
$C W$, coastal waters; sea surface temperature [SST]: $s T W$, sub-tropical waters; $A R F$, Aguhlas current return front; others, sub-tropical front, sub-Antarctic south waters, sub-Antarctic front, polar frontal zone and polar front)

\begin{tabular}{|lcccl|}
\hline Variable & Wilk's $\lambda$ & p-value & Year effect & Habitat ranking \\
\hline Bathymetry & 0.092 & $<\mathbf{0 . 0 0 1}$ & 0.178 & P. Slope $>>>$ OC $>>>C W$ \\
SST & 0.428 & $<\mathbf{0 . 0 0 1}$ & $\mathbf{< . 0 0 1}$ & ARF $>$ sTW $>>$ others \\
1996 & & $<\mathbf{0 . 0 0 1}$ & - & $S T W>>>A R F>>>$ others \\
2001 & & $<\mathbf{0 . 0 0 1}$ & - & $A R F>>>$ STW $>>$ others \\
\hline
\end{tabular}

the largest interannual variation among the prey fish, representing $62 \%$ of prey numbers in 1996, while, in 2001, this proportion fell to $37 \%$. During 1996 and 2001, squids appeared in 34 and $48 \%$ of the samples (6.9 and $13.4 \%$ by mass), while the frequency of occurrence of crustaceans was more variable, with 29 and $84 \%$, respectively ( 0.6 and $1.4 \%$ by mass). The large mysid shrimp Neognathophausia ingens was the main crustacean prey, and was present in $56 \%$ of the samples in 2001 versus $15 \%$ in 1996.

\section{Provisioning parameters}

Foraging trips were longer in 2001 than in 1996 (1996: $1.78 \pm 1.27 d(n=50), 2001: 2.87 \pm 2.32 d(n=40)$, Kruskal-Wallis test, $U=726, \mathrm{p}=0.02$, see Fig. 4A). We tested the existence of a bimodal distribution of trip length in 1996 and 2001 according to Efron \& Tibshirami (1993), with a bootstrap simulation with 10000 trials and $H_{0}$ : the distribution has 2 modes. The null hypothesis was rejected for 1996 ( $p=0.05$ ), while we cannot reject it for $2001(\mathrm{p}=0.22)$, indicating that the distribution of trip length in 2001 was bimodal, with a higher proportion of long trips compared to 1996.

The mass of meals did not differ between years (1996: $468 \pm 173 \mathrm{~g}, \mathrm{n}=$ 32; 2001: $408 \pm 142 \mathrm{~g}, \mathrm{n}=75$, ANOVA, $F_{1,105}=3.57, \mathrm{p}=0.061$, Fig. $\left.4 \mathrm{~B}\right)$. Taking into account both trip length and meal size, the provisioning rate (calculated over $5 \mathrm{~d}$ in mid-January with nests with complete data during this period) was lower in 2001 than in 1996 (1996: $325 \pm 137 \mathrm{~g} \mathrm{~d}^{-1}$ ( $\mathrm{n}=15$ nests), 

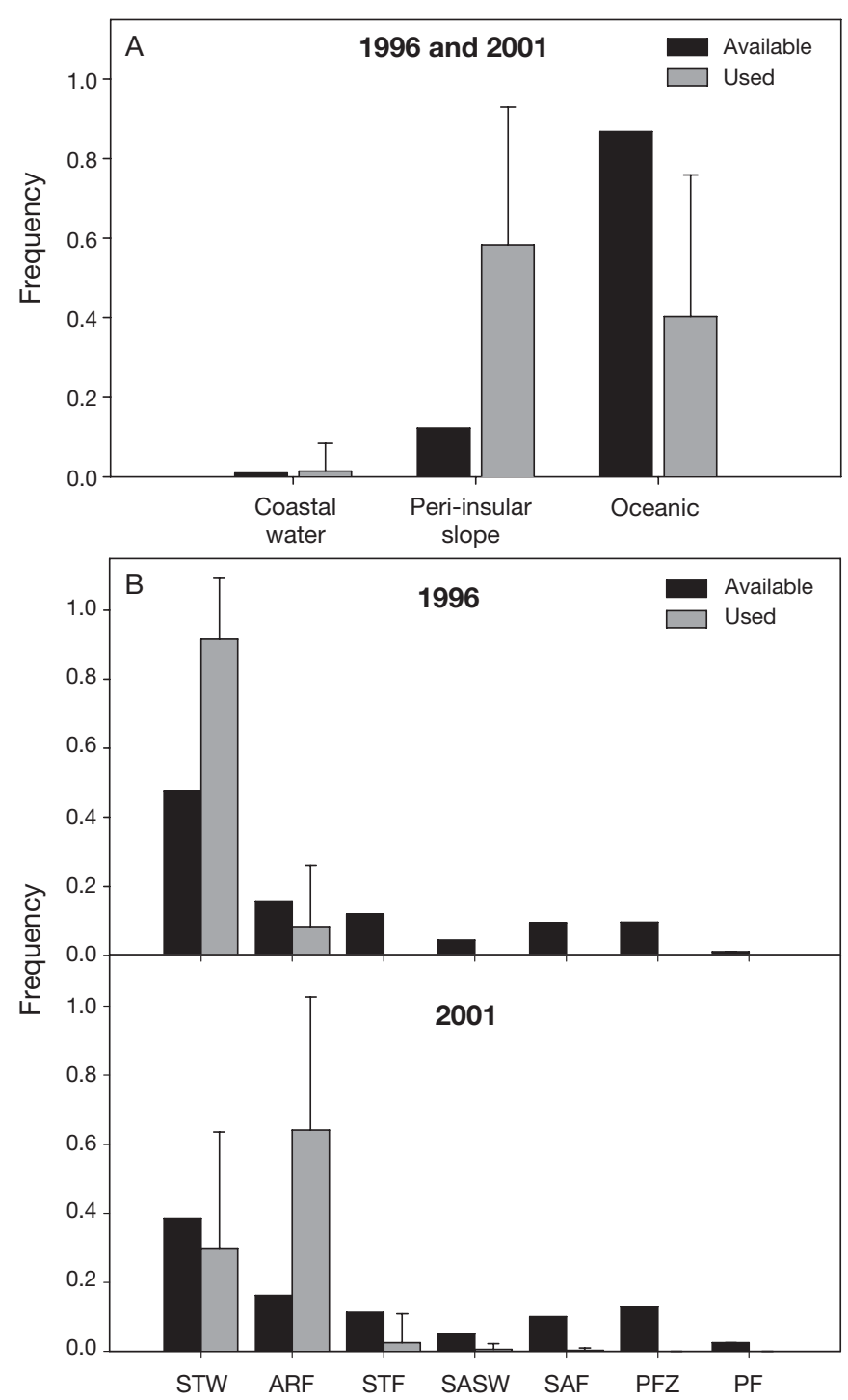

Fig. 3. Thalassarche chlororhynchos. Proportions of available and used oceanographic habitats defined by: (A) bathymetry (years pooled) and (B) SST, in January 1996 and 2001. Compositional analysis indicates a significant difference in habitat use between years for SST (for abbreviations, see Table 1 legend)

2001: $152 \pm 87 \mathrm{~g} \mathrm{~d}^{-1}$ ( $\mathrm{n}=25$ nests), Kruskal-Wallis test, $U=54, \mathrm{p}<0.001$, Fig. 4C), i.e. chicks in 1996 received twice as much food in mass than those in 2001.

\section{Consequence for chick growth}

For the same study dates (age), chicks in 1996 were heavier than in 2001 (Fig. 5; ANOVA repeated measures on chicks still alive at the end of March (40 in 1996, 11 in 2001; dependent variable: mass; effect of time: $F_{1,49}=134.9, \mathrm{p}<0.001$; year: $F_{1,49}=22.9, \mathrm{p}<$
0.001; time $\times$ year: $\left.F_{1,49}=10.2, \mathrm{p}=0.002\right)$. Differences in chick weight between years were greater in January, but tended to decrease at the end of the breeding period. However, no difference in chick survival was observed (Fig. 5). Wing length at fledging showed no significant difference between the 2 years (ANOVA, $F_{1,49}=0.051, \mathrm{p}=0.822$ ).

\section{Adult mass}

There was no significant difference between years in adult mass after a feeding event. For the period between 15 and 18 January, mean adult mass was $2138 \pm 139 \mathrm{~g}(\mathrm{n}=8)$ in 1996 and $2166 \pm 225 \mathrm{~g}(\mathrm{n}=29)$ in 2001 (Mann-Whitney test, $U=124.5, \mathrm{p}=0.75$ ). For the period between 10 and 12 February, adult mass was, on average, $2110 \pm 198 \mathrm{~g}(\mathrm{n}=18)$ in 1996 and $2247 \pm 233 \mathrm{~g}(\mathrm{n}=15)$ in 2001 (Mann-Whitney test, $U=$ 182, $\mathrm{p}=0.09$ ).

\section{DISCUSSION}

Changes in provisioning parameters and reproductive performance in relation to food availability have increasingly been documented in seabird and marine mammal populations (e.g. Croxall et al. 1999), and it has been suggested that marine resources can be monitored by studying the provisioning parameters of these populations (Montevecchi 1993). However, interannual comparisons have concerned mainly surveys at colony sites, and changes in behaviour at sea are still poorly known (see Barlow \& Croxall 2002). Here, we show that birds changed their foraging locations and habitat use in 2 contrasting years and that these changes had consequences for chick growth. When considering the consequences for provisioning parameters and reproduction, 2001 could be categorised as a year with a lower prey availability for yellow-nosed albatrosses breeding on Amsterdam Island, compared to 1996.

\section{Environmental conditions, diet and distribution at sea}

Environmental conditions differed between 1996 and 2001 around Amsterdam Island, as evidenced by SST characteristics of water masses. The distribution of water masses and the position of fronts differed markedly, the $18^{\circ} \mathrm{C}$ isotherm (ARF northern boundary, Holliday \& Read 1998) was located further south, i.e. closer to the colony, in 1996. Such SST variations are known to strongly affect marine ecosystems (Hyren- 
Table 2. Thalassarche chlororhynchos. Diet during the chick rearing period (January) in 1996 and 2001. Samples were collected from adult and chick regurgitations

\begin{tabular}{|c|c|c|c|c|c|c|c|c|}
\hline & \multicolumn{4}{|c|}{$1996(\mathrm{n}=41)$} & \multicolumn{4}{|c|}{$2001(\mathrm{n}=25)$} \\
\hline & \multicolumn{2}{|c|}{ Frequency of occurrence } & \multicolumn{2}{|c|}{ Number of item } & \multicolumn{2}{|c|}{ Frequency of occurrence } & \multicolumn{2}{|c|}{ Number of item } \\
\hline & $\mathrm{n}$ & $\%$ & $\mathrm{n}$ & $\%$ & $\mathrm{n}$ & $\%$ & $\mathrm{n}$ & $\%$ \\
\hline Fish & 41 & 100.0 & 196 & 85.5 & 23 & 92.0 & 109 & 67.3 \\
\hline Phosichthys argenteus & 6 & 14.6 & 6 & 2.6 & 5 & 20.0 & 8 & 4.9 \\
\hline Scomberesox saurus & 20 & 48.8 & 37 & 16.2 & 8 & 32.0 & 17 & 10.5 \\
\hline Cubiceps caeruleus & 36 & 87.8 & 141 & 61.6 & 16 & 64.0 & 60 & 37.0 \\
\hline Squid & 14 & 34.1 & 15 & 6.6 & 12 & 48.0 & 13 & 8.0 \\
\hline Crustacean & 12 & 26.3 & 13 & 5.7 & 21 & 84.0 & 32 & 19.8 \\
\hline Neognathophausia ingens & 6 & 14.6 & 6 & 2.6 & 14 & 56.0 & 18 & 11.1 \\
\hline Others & 5 & 12.2 & 5 & 2.2 & 4 & 16.0 & 8 & 4.9 \\
\hline Total & & & 229 & 100.0 & & & 162 & 100.0 \\
\hline
\end{tabular}
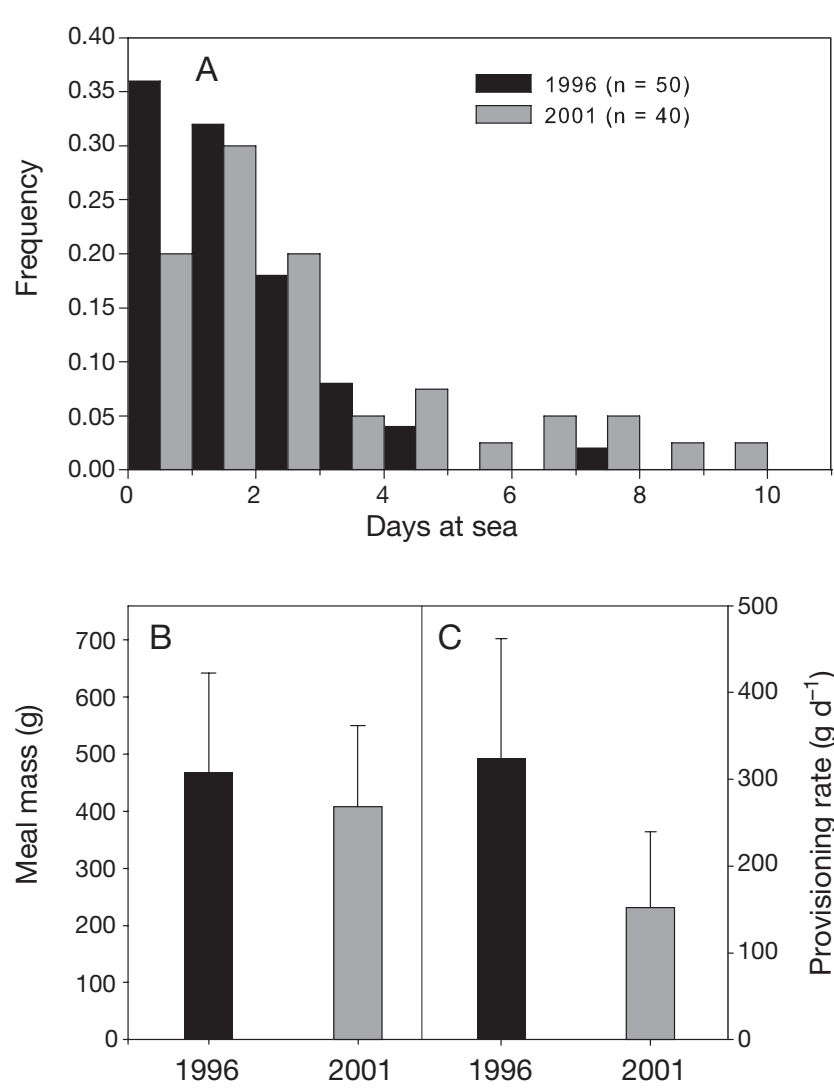

Fig. 4. Thalassarche chlororhynchos. (A) Distribution of foraging trip durations in January 1996 and 2001. Trips in 2001 are significantly longer (Kruskal-Wallis test, $U=726, \mathrm{p}=0.02$ ). Note that the 2001 distribution tends to be bimodal. (B) Mass of meals delivered by adults from Amsterdam Island in January 1996 and 2001. Meals in 2001 tended to be lighter, but this difference is not significant (ANOVA, $F_{1,105}=3.57, \mathrm{p}=0.061$ ). (C) Provisioning rate $\left(\mathrm{g} \mathrm{d}^{-1}\right)$, calculated as food delivered during $5 \mathrm{~d}$ in mid-January, for yellow-nosed albatross from Amsterdam Island in 1996 and 2001. Chicks in 2001 received half the food in mass as those in 1996 on the same date (KruskalWallis test, $U=54, \mathrm{p}<0.001$ ) bach \& Veit 2003) and the physical structure of the ocean (e.g. mixed layer, Waluda et al. 1999), which in turn controls, in part, primary and secondary production (Hyrenbach \& Veit 2003). In consequence, during such contrasting environmental situations, prey accessibility and availability are expected to change for predators, especially for central-place foragers (Croxall et al. 1999). Environmental conditions changed between 1996 and 2001, and birds did not use marine habitat in the same way. Compared to 1996, when waters around Amsterdam Island were warmer, albatrosses in 2001 foraged mainly south of the colony, reaching colder oceanic domains. In 2001, they foraged farther from the colony than in 1996 and in different oceanic domains, up to $1500 \mathrm{~km}$ from their nest, reflecting potential difficulties in finding food close to the colony. In terms of habitat use with respect to bathymetry, no differences were noted, probably as a result of the high utilisation of waters around the colony (due to the central-place constraint, Rosenberg \& McKelvey 1999) that masked the small difference between the 2 years. Using satellite telemetry, Veit \& Prince (1997) showed that blackbrowed albatrosses Thalassarche melanophris tended to be distributed farther from their colony at South Georgia when abundance of their main prey (Antarctic krill Euphausia superba) was low. This shows that, when prey availability is lower in the vicinity of breeding sites, top-predators change their foraging and forage further to exploit distant resources, although very low breeding success can be observed during these conditions (Sydeman et al. 2001).

Because environmental conditions changed and albatrosses foraged in different oceanic domains, we could expect some changes in their diet. In fact, during both years, the prey taken was dominated by fish, including 2 mesopelagic (Cubiceps caeruleus and Phosichthys argenteus) and 1 epipelagic (Scomberesox 


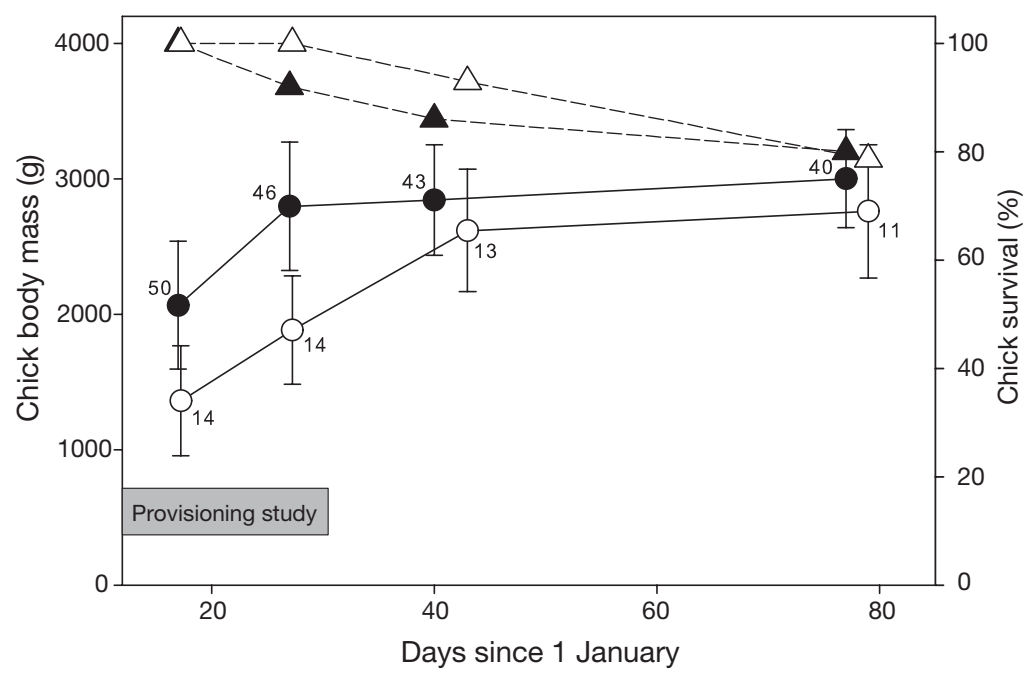

Fig. 5. Thalassarche chlororhynchos. Chick body mass (circles) and survival (triangles) in January 1996 (filled) and 2001 (open), from mid-January (chicks are ca. $44 \mathrm{~d}$ old on this date) to late March (ca. $100 \mathrm{~d}$ old chicks, just before fledging). These data included the same sample of chicks for calculation of mass and survival, 50 for 1996 and 14 for 2001

saurus) sub-tropical/temperate species (Hubbs \& Wisner 1980, Agafonova 1994). However, a significant difference was noted between 1996 and 2001, with more fish (including C. caeruleus) and less squid and crustaceans (including Neognathaphausia ingens) being caught in 1996. Squids are generally considered to be energetically less valuable prey than fish for seabirds, including albatrosses (Prince 1985). Consequently, a lower nutritional quality of prey, together with a lower energy flux to the chicks, is the most likely explanation of the slower growth of chicks in 2001 when compared to 1996.

The observed interannual difference in diet suggests that albatrosses were feeding on different proportions of the same prey, as found for other species of seabirds during years of lower primary prey availability (Suryan et al. 2002, Xavier et al. 2003). This flexibility in seabird foraging behaviour could reach certain limits, as suggested by our interannual comparison, beyond which nestling growth and, potentially, survival are negatively affected.

\section{Provisioning parameters and effect on chicks}

In 2001, adults spent more time at sea, but meal mass was not significantly different, leading to a decrease in the provisioning rate. Thus, birds appear to maximise food loads at the expense of feeding frequency. It is, therefore, feeding frequency that changes between years and affects provisioning rates and, consequently, chick growth, as has been found using interannual comparisons on these (Weimerskirch et al. 2001) and other seabird species (Suryan et al. 2002), or with inter-colony comparisons of common murres using different distances to prey resources (Davoren \& Montevecchi 2003). Similar results have also been obtained for yellow-nosed albatross when foraging costs were experimentally increased (Weimerskirch et al. 2000). We showed here, under natural conditions, that the increase in yellow-nosed albatross trip length is mainly a consequence of a switch to exploiting foraging grounds located farther from the colony. As a consequence of this increase in trip length, the amount of food per unit of time provided to the chick in 2001 was half the amount provided in 1996.

The high proportion of long trips in 2001, leading to a bimodal distribution of trip length, was not observed in 1996. The strategy of an alternation of short and long trips has been previously observed in this species, but only during years with adverse environmental conditions (Weimerskirch et al. 2001). For yellow-nosed albatross, this provisioning strategy seems to be facultative and dependent upon environmental conditions around the breeding site (as found also for Cory's shearwaters, Granadeiro et al. 1998), and allows the combination of a sufficient provisioning rate for the chick with a restoration of body reserves for the adult (see Weimerskirch 1999). As a consequence, no significant difference in adult body mass was observed between 1996 and 2001. The bimodal strategy was also found to be flexible in another albatross species, the black-browed albatross, but at the species level (Waugh et al. 2000, see Balduini \& Hyrenbach 2003 for a review). During the fledging period, the populations at Campbell Island adopt a 2-fold strategy to exploit distant resources, while the more neritic populations of South Georgia and Kerguelen mainly used short trips. These changes in prey-acquisition processes ultimately had consequences for reproduction. Chicks were lighter in 2001, with a maximum difference in body mass at ca. $60 \mathrm{~d}$ old. This is in accordance with the differences observed in foraging distribution and provisioning rate, suggesting that January 2001 was a period with low prey availability in the vicinity of the breeding site. Despite the fact that prey availability cannot be sampled over vast foraging ranges, our study revealed that changes in environmental conditions affected the foraging distribution and habitat use of yellow-nosed albatross, leading to differences in trip length, provisioning rate and, ultimately, chick growth; however, no impact on adult condition was detected. 
When prey availability is lower in the vicinity of breeding sites, these top-predators adapt their foraging strategy and switch to exploit distant resources. This flexibility could present some limits beyond which chick growth is negatively affected. Our study demonstrates that prey distribution is critical to understanding the ecology and population variations of centralplace foragers like seabirds.

Acknowledgements. This study received financial support from the Institut Paul-Emile Victor (Program No. 109) and the Centre National pour la Recherche Scientifique. D.P. was supported by a grant from Ecole Doctorale 'Sciences de la Vie et de la Santé' from Strasbourg University. Protocols and procedures were approved by the Ethical Committee of the Institut Paul-Emile Victor. We would like to thank all people involved in fieldwork: L. Zimmermann, F. LeBouard, S. Schaffer, H. Saen and P.A. Prince, and the people from the 33th and 38th Amsterdam missions, and for help with spatial analysis and programming: L. Dubroca, T. Cornulier, O. Duriez, E. Corda and C. Calenge. Many thanks to C. Trouvé for help with diet analysis. We thank 3 anonymous referees for constructive comments, which greatly improved the manuscript.

\section{LITERATURE CITED}

Aebischer NJ, Robertson PA, Kenward RE (1993) Compositional analysis of habitat use from animal radio-tracking data. Ecology 74:1313-1325

Agafonova TB (1994) Systematics and distribution of Cubiceps (Nomeidae) of the world ocean. J Ichthyol 34:116-143

Alerstam T, Gudmundsson GA, Larsson B (1993) Flight tracks and speeds of Antarctic and Atlantic seabirds: radar and optical measurements. Phil Trans R Soc Lond B 340:55-67

Ashmole NP (1971) Seabird ecology and the marine environment. Avian Biol 1:223-286

Baduini CL, Hyrenbach KD (2003) Biogeography of procellariiform foraging strategies: does ocean productivity influence provisioning? Mar Ornithol 31:101-112

Barlow KE, Croxall JP (2002) Seasonal and interannual variation in foraging range and habitat of macaroni penguins Eudyptes chrysolophus at South Georgia. Mar Ecol Prog Ser 232:291-304

Cherel Y, Weimerskirch H, Trouvé C (2000) Food and feeding ecology of the neritic-slope forager black-browed albatross and its relationships with commercial fisheries in Kerguelen waters. Mar Ecol Prog Ser 207:183-199

Clarke MR (1986) A handbook for the identification of cephalopod beaks. Clarendon Press, Oxford

Croxall JP (1982) Energy costs of incubation and moult in petrels and penguins. J Anim Ecol 51:177-194

Croxall JP (1992) Southern Ocean environmental changes: effects on seabird, seal and whale populations. Phil Trans R Soc Lond B 338:319-328

Croxall JP, Reid K, Prince PA (1999) Diet, provisioning and productivity responses of marine predators to differences in availability of Antarctic krill. Mar Ecol Prog Ser 177:115-131

Davoren GK, Montevecchi WA (2003) Consequences of foraging trip duration for provisioning behaviour and fledging condition of common murres Uria aalge. J Avian Biol 34: $44-53$

Efron B, Tibshirani RJ (1993) An introduction to the bootstrap. Chapman \& Hall, New York

Granadeiro JP, Nunes M, Silva MC, Furness RW (1998) Flexi- ble foraging strategy of Cory's shearwater, Calonectris diomedea, during the chick-rearing period. Anim Behav 56:1169-1176

Hays GC, Akesson S, Godley BJ, Luschi P, Santidrian P (2001) The implications of location accuracy for the interpretation of satellite-tracking data. Anim Behav 61:1035-1040

Holliday NP, Read JF (1998) Surface oceanic fronts between Africa and Antarctica. Deep-Sea Res I 45:217-238

Hubbs CL, Wisner RL (1980) Revision of the sauries (Pisces, Scomberesocidae) with descriptions of two new genera and one new species. Fish Bull (Wash DC) 77:521-566

Hunt GL Jr (1991) Occurrence of polar seabirds at sea in relation to prey concentrations and oceanographic factors. Polar Res 10:553-559

Hyrenbach KD, Veit RR (2003) Ocean warming and seabird communities of the California Current System: response at multiple temporal scales. Deep-Sea Res II 50:2537-2565

Inchausti P, Guinet C, Koudil M, Durbec JP, Barbraud C, Weimerskirch H, Cherel Y, Jouventin P (2003) Interannual variability in the breeding performance of seabirds in relation to oceanographic anomalies that affect the Crozet and the Kerguelen sectors of the Southern Ocean. J Avian Biol 34:170-176

Jouventin P, Roux JP, Stahl JC, Weimerskirch H (1983) Biologie et fréquence de reproduction chez l'albatros à bec jaune (Diomedea chlororhynchos). Gerfaut 73:161-171

Marchant S, Higgins PJ (1990) Yellow-nosed albatross Diomedea chlororhynchos. Handbook of Australian, NewZealand \& Antarctic birds, Vol 1, Part A. Oxford University Press, Melbourne, p 126-147

Montevecchi WA (1993) Birds as indicators of change in marine prey stocks. In: Furness RW, Greenwood JJD (eds) Birds as monitors of environmental change. Chapman \& Hall, London, p 217-266

Murano M (1999) Mysidacea. In: Boltovskoy D (ed) South Atlantic zooplankton. Backhuys Publishers, Leiden, p 1099-1140

Orians GH, Pearson NE (1979) On the theory of central place foraging. In: Horn DJ, Stairs GR, Mitchell RD (eds) Analysis of ecological systems. Ohio State University Press, Colombus, OH, p 155-177

Pennycuick CJ (1982) The flight of petrels and albatrosses (Procellariiformes), observed in South Georgia and its vicinity. Phil Trans R Soc Lond B 300:75-106

Phillips RA, Xavier JC, Croxall JP (2003) Effects of satellite transmitters on albatrosses and petrels. Auk 120: 1082-1090

Pinaud D, Weimerskirch H (2002) Ultimate and proximate factors affecting the breeding performance of a marine top-predator. Oikos 99:141-150

Prince PA (1985) Population and energetic aspects of the relationship between black-browed and grey-headed albatrosses and the Southern Ocean marine environment. In: Siegfried WR, Condy PR, Laws RM (eds) Antarctic nutrient cycles and food webs. Springer, Berlin, p 473-477

R Development Core Team (2003) R: a language and environment for statistical computing. (1.8.1). R Foundation for Statistical Computing, Vienna

Reynolds RW, Smith TM (1994) Improved global sea surface temperature analyses. J Clim 7:929-948

Ricklefs RE, Day CH, Huntington CE, Williams JB (1985) Variability in feeding rate and meal size of Leach's stormpetrel at Kent Island, New Brunswick. J Anim Ecol 54: 883-898

Rosenberg DK, McKelvey KS (1999) Estimation of habitat selection for central-place foraging animals. J Wildl Manag 63:1028-1038 
Schreiber RW, Schreiber EA (1984) Central Pacific seabirds and the El Niño Southern Oscillation: 1982 to 1983 perspectives. Science 225:713-716

Smale MJ, Watson G, Hecht T (1995) Otolith atlas of Southern African marine fishes. JBL Smith Institute of Ichthyology, Grahamstown

Stearns SC (1992) The evolution of life histories. Oxford University Press, Oxford

Suryan RM, Irons DB, Kaufman M, Benson J, Jodice PGR, Roby DD, Brown ED (2002) Short-term fluctuations in forage fish availability and the effect on prey selection and brood-rearing in the black-legged kittiwake Rissa tridactyla. Mar Ecol Prog Ser 236:273-287

Sydeman WJ, Hester MM, Thayer JA, Gress F, Martin P, Buffa $\mathrm{J}$ (2001) Climate change, reproductive performance and diet composition of marine birds in the southern California Current system, 1969-1997. Prog Oceanogr 49:309-329

Veit RR, Prince PA (1997) Individual and population level dispersal of black-browed albatrosses Diomedea melanophris and grey-headed albatrosses D. chrysostoma in response to antarctic krill. Ardea 85:129-134

Waluda C, Trathan P, Rodhouse P (1999) Influence of oceanographic variability on recruitment in the Ilex argentinus

Editorial responsibility: Otto Kinne (Editor-in-Chief), Oldendorf/Luhe, Germany
(Cephalopoda: Ommastrephidae) fishery in the South Atlantic. Mar Ecol Prog Ser 183:159-167

Waugh SM, Weimerskirch H, Cherel Y, Prince PA (2000) Contrasting strategies of provisioning and chick growth in two sympatrically breeding albatrosses at Campbell Island, New Zealand. Condor 102:804-813

Weimerskirch H (1999) The role of body condition in breeding and foraging decision in albatrosses and petrels. In: Adams NJ, Slotow RH (eds) Proc 22th Int Ornithol Congr. BirdLife South Africa, Durban, p 1178-1189

Weimerskirch H, Jouventin P, Stahl JC (1986) Comparative ecology of six albatross species breeding on the Crozet Islands. Ibis 128:195-213

Weimerskirch H, Prince PA, Zimmermann L (2000) Chick provisioning by the yellow-nosed albatross Diomedea chlororhynchos: response of foraging effort to experimentally increased costs and demands. Ibis 142:103-110

Weimerskirch H, Zimmermann L, Prince PA (2001) Influence of environmental variability on breeding effort in a long-lived seabird, the yellow-nosed albatross. Behav Ecol 12:22-30

Xavier JC, Croxall JP, Reid K (2003) Interannual variation in the diet of two albatross species breeding at South Georgia: implications for breeding performance. Ibis 145:593-610

Submitted: October 28, 2004; Accepted: May 5, 2005

Proofs received from author(s): June 30, 2005 